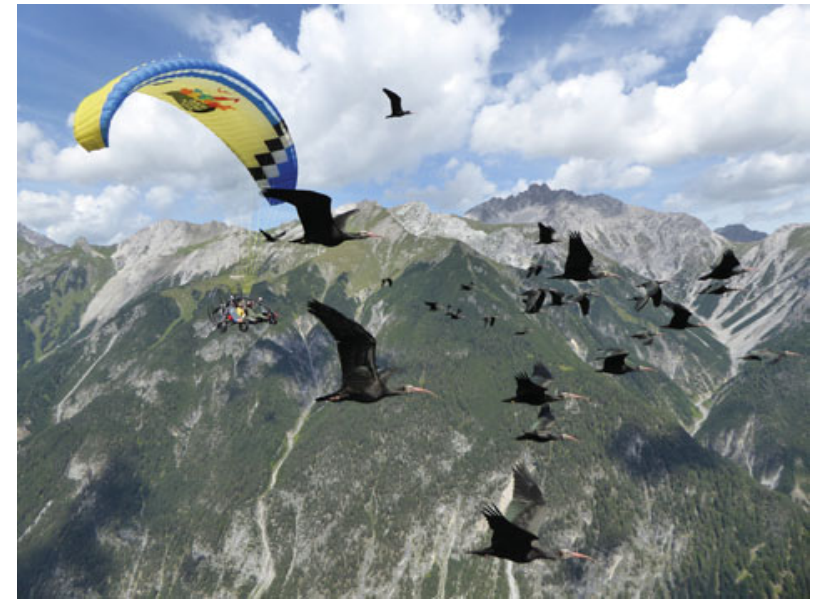

Microlight piloted by a foster parent leading northern bald ibises to the wintering site in southern Tuscany, Italy. Photo: Waldrappteam Conservation \& Research.

by human foster parents. After fledging the birds undergo a training programme to follow two microlights co-piloted by the foster parents. From mid August this migration leads in flight stages of c. $220 \mathrm{~km}$ per day from the breeding sites north of the Alps over c. 1,00o km to the wintering site in southern Tuscany, where the birds are released. During 2014-2019 a total of 154 birds were released. No release occurred in 2020 because of the COVID-19 pandemic.

First-year survival of the released juveniles is 0.73 , significantly higher than the 0.31 first-year survival of released juveniles in the Spanish Proyecto Eremita (Böhm et al., 2020, Oryx, 55, 934-946). We attribute the high survival rate of released birds in our project to the complex prerelease training and low loss during the human-led migration. Reproduction in the released population has increased steadily. During 2014-2020, 151 birds in 61 nests fledged in the wild, a mean fledging rate of 2.47 per nest. This is double the fledging rate of 1.23 per nest in the last remaining wild population in Morocco. The high fledging rate in the LIFE+ project reflects the high-quality feeding habitats in the breeding areas north of the Alps.

A recent population viability analysis indicates that the reintroduced population is close to sustainability but that further releases and management will be needed. This will be under a second European LIFE project, run by Zoo Vienna with partners from Germany, Austria, Italy and Switzerland, aiming to establish further migratory colonies in Austria, Switzerland and northern Italy, and a total population size of $>350$ individuals.

JOHANNES FRITZ (๑ orcid.org/0000-0003-4691-2892) Waldrappteam Conservation \& Research, Mutters, Austria, and IUCN Species Survival Commission, Stork, Ibis and Spoonbill Specialist Group. E-mail jfritz@waldrapp.eu

This is an Open Access article, distributed under the terms of the Creative Commons Attribution licence CC BY 4.0.

\section{Hope for an apex predator: giant otters rediscovered in Argentina}

The giant otter Pteronura brasiliensis, categorized as Endangered on the IUCN Red List, is an apex predator in Neotropical freshwater systems with the potential to regulate food webs through density-mediated trophic cascades (Quéméré et al., 2021, Environmental DNA, in press). The giant otter has been extirpated in some countries and extant populations are declining.

Giant otters were once abundant in Argentina but heavy hunting, habitat loss and degradation resulted in their dramatic decline. The last known population disappeared in the 1980s. Since then, records of solitary individuals have been reported in the Iguazú and Paraná River basins, the most recent from 2010, but these records lack supporting evidence such as images or signs. In the Bermejo River basin, in the Chaco region, the last sightings of giant otters date from the late 1800 .

El Impenetrable National Park, created in 2017, protects the declining dry forests of the Chaco region. To the north, the Park is bounded by the Bermejo River. On 16 May 2021 in $\mathrm{El} \mathrm{Breal,} \mathrm{one} \mathrm{of} \mathrm{several} \mathrm{ponds} \mathrm{formed} \mathrm{by} \mathrm{old} \mathrm{meanders}$ of this river, SDM observed an adult giant otter and secured a photograph. Surveys later that day revealed two fresh latrines and two recently dug dens on the shore. El Breal pond has steep clayey shorelines $2-3 \mathrm{~m}$ above the highest water level and a total surface water area of 0.37 $\mathrm{km}^{2}$. Water depth is c. $10 \mathrm{~m}$ and potential giant otter prey in the pond include abundant fish, macroinvertebrates and caimans. A mature dry forest surrounds the pond.

The origin of this individual is unknown. The closest giant otter population is in the Jejuí River in Paraguay, close to its confluence with the Paraguay River (Cartes et al., 2013, Paraquaria Natural, 1, 8-11). But an animal dispersing from there would have to travel c. 1,00o km of waterways to reach El Impenetrable National Park. Alternatively,

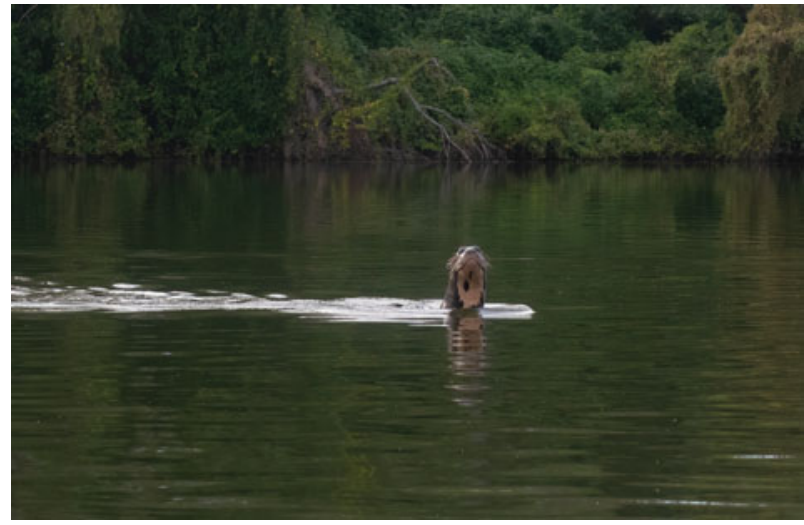

Giant otter photographed in El Impenetrable National Park, Argentina, in May 2021. Photo: Sebastián Di Martino. 
this individual could be part of a previously unrecorded relictual population. Genetic analysis of fecal samples could shed light on this.

Using camera traps, we have identified the animal as a male and found no evidence of other accompanying giant otters. To ensure the survival of this individual, it is paramount that deforestation around the Park is halted and any poaching in the Bermejo River deterred. Federal and provincial governments need to work together to increase patrolling in the lands around the Park and along rivers. Conservation translocations of captive-bred and wild individuals could be considered, to increase the likelihood of establishing a founding population.

CAROLINE LEUCHTENBERGER (๑ orcid.org/0000-0002-16392593) Federal Institute of Education Science and Technology of Farroupilha, Santa María, Brazil

Sebastián Di Martino, GeRARdo Cerón (๑ orcid.org/00000003-2723-4205), ALEJANDRO SERRANO-SPONTÓN (○ orcid.org/ 0000-0002-6048-4583) and EMILIANO DONADIO (ㄷ orcid.org/ 0000-0001-5257-4100) Fundación Rewilding Argentina,

Buenos Aires, Argentina

E-mail edonadio@rewildingargentina.org

This is an Open Access article, distributed under the terms of the Creative Commons Attribution licence CC BY 4.0.

\section{Giant otters are negatively affected by a new hydropower dam in the most protected state of the Brazilian Amazon}

The giant otter Pteronura brasiliensis is endemic to South America and categorized as Endangered on the IUCN Red List. The Amazon basin is one of the last strongholds for this species, yet recent human expansion across Amazonia has led to an increase in the number of hydropower dams, which negatively affect both freshwater and terrestrial biodiversity. Although areas with low human population density that held giant otters before dam construction may have potential for the conservation of the species (Rosas et al., 2007, Oryx, 41, 520-524), there has been no previous robust documentation of the impacts of hydropower developments on the species.

We conducted a before-after control-impact study to evaluate the effects of a new run-of-river hydropower dam on giant otters in the State of Amapá, eastern Brazilian Amazon. This state has the lowest deforestation rates and the highest territorial coverage of protected areas among all states of the Legal Brazilian Amazon, and has low human population densities. In surveys before (2011-2013 and 2015) and after (2016-2020) the construction of a large run-of-river hydropower dam (219 MW, height $20.6 \mathrm{~m}$, reservoir covering $47.99 \mathrm{~km}^{2}$ ) we surveyed a total of $9,356 \mathrm{~km}$ along $139 \mathrm{~km}$ of rivers by boat.
There was a relatively constant detection rate in the control zone $>70 \mathrm{~km}$ upstream of the dam (0.11 and 0.10 detections $/ 10 \mathrm{~km}$ before and after, respectively). In the directly impacted zone $(<50 \mathrm{~km}$ upstream of the dam, as established in the environmental impact assessment) the detections declined (0.03 and o detections/10 $\mathrm{km}$ before and after, respectively), with no evidence that giant otters remained in the impacted zone. Considering this region has a high coverage of protected areas, low deforestation rates (forest cover $>90 \%$ in the control zone) and a low human population density, it is imperative to emphasize the importance of mitigation to minimize the negative effects of new and planned hydropower dams. We expect that, in the absence of effective mitigation actions, the increasing number of new hydropower dams across Amazonia are likely to cause further reductions in giant otter populations. Contrary to portrayal in the media, run-of-river dams are not necessarily eco-friendly. Government efforts for more sustainable energy generation using a combination of technologies (e.g. in-stream turbines, solar and wind power) need to be reinforced.

FERNANDA MiCHALSKI (๑ orcid.org/0000-0002-8074-9964) Ecology and Conservation of Amazonian Vertebrates Research Group, Federal University of Amapá, Macapá, Amapá, Brazil, and Pro-Carnivores Institute, Atibaia, São Paulo, Brazil.E-mail fmichalski@gmail.com

DARREN NORRIS (@ orcid.org/0000-0003-0015-8214) School of Environmental Sciences, Federal University of Amapá, Macapá, Amapá, Brazil

This is an Open Access article, distributed under the terms of the Creative Commons Attribution licence CC BY 4.0 .

\section{Biodiversity hotspot and Ramsar site under threat}

Ndumo Game Reserve in South Africa, bordering Mozambique, is facing an existential threat and may not make its 1ooth anniversary in 2024. Ndumo, gazetted to protect the Vulnerable hippopotamus Hippopotamus amphibious, lies within the Maputaland-Pondoland Centre of Endemism and Biodiversity Hotspot. The northern and eastern borders were originally the Usuthu and Phongolo Rivers, respectively, but the Usuthu has since shifted course to flow through the Reserve. Mozambique now has claims on Reserve land north of the river, and Mozambicans have access to unfenced Reserve land.

An additional problem is illegal farming on the Phongolo floodplain in the eastern part of the Reserve. Ndumo protects $10 \%$ of the 13,000 ha floodplain, a major reason why Ndumo is a Ramsar Wetland of International Importance. This floodplain has the richest fish fauna of any river system in South Africa. Fishes breed there and migrate into the surrounding 